\title{
Conformity of Physical Characteristics of Imported Tires with Government Standards: A Case Study
}

\author{
N.T. Ratrout*1, S. Anwar Basha1, H. I. Al-Abdul Wahhab¹ and K. A. Al-Ofi1,2 \\ ${ }^{1}$ Department of Civil Engineering, King Fahd University of Petroleum \& Minerals, Dhahran 31261, Saudi Arabia \\ ${ }^{2}$ Research Institute, King Fahd University of Petroleum \& Minerals, Dhahran 31261, Saudi Arabia.
}

Received 19 March 2003; accepted 7 July 2003

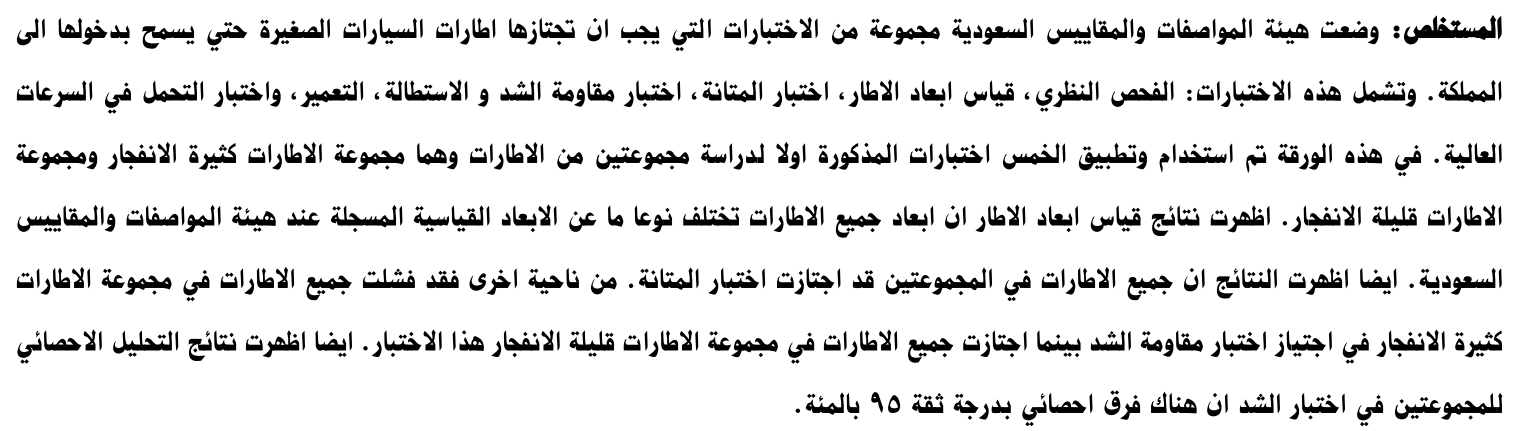

الهزردات الهنتامية: ساسو، اختبارات الاطارات، اختبار المتانة، الاطارات بالمهلكة العربية السعودية.

\begin{abstract}
The Saudi Arabian Standards Organization, SASO, has established a set of tests that all passenger car tires have to pass in order to be allowed into the Country. These tests are: visual inspection, dimension measurement, bead unseating, tensile strength and elongation, aging, endurance, and high speed performance tests. This paper describes the application of the first five tests on eight different brands of tires that are taken to represent the categories of "frequently failed" and "infrequently failed" tires in the country. The results showed that the dimensions of almost all the tested tires were somewhat different from those documented in the SASO standards. On the other hand, all the tested tires passed the bead unseating and strength tests. All tires in the "frequently failed" category failed the tensile strength test. In contrast, all tires from the "infrequently failed" category passed this test. The average values of the test for these two tire categories were statistically different at a $95 \%$ confidence level.
\end{abstract}

Key words: SASO tests, tire tests, bead unseating test, tires in Saudi Arabia.

\section{Introduction}

The Saudi Arabian Standards Organization, SASO, is the sole standardization body in the Country. The Ministry of Commerce, in association with SASO, has established a comprehensive certification program termed the International Conformity Certification Program. It is a combined assessment program, which deals with a preshipment inspection and a certification scheme. Based on these inspection guidelines, various consignments are allowed into the country. It applies to approximately 66 categories of products, and includes new tires for all kinds of imported automobiles (Ministry of Commerce, 2001).

*Corresponding author E-mail: nratrout@kfupm.edu.sa
SASO Standard No.448/1986 deals with the methods of testing that are performed on tires in order to obtain a conformity certificate (Saudi Arabian Standard Organization, 1986a). SASO Standard No. 447/1986, on the other hand, documents the values of these tests that have to be satisfied (Saudi Arabian Standard Organization, 1986b). These standards have been in effect since 1987 and are similar to the U.S. Federal Motor Vehicle Safety Standard No.109 (National Highway Traffic, 2001). This federal standard specifies the tire dimension and laboratory test requirements for bead unseating resistance, strength, endurance, and high speed performance that are applicable to all passenger car pneumatic tires manufactured after 1948.

The objective of this paper was to examine the conformity of imported tires with SASO standards and to assess their physical characteristics based on these standards. 
SASO Standard No. 448/1986 describes eight tests for passenger car tires, namely visual inspection, dimension measurement, bead unseating, strength, tensile strength and elongation, aging, endurance, and high speed performance. This paper summarizes the results of the first five tests that were conducted on abroad sample of imported tire brands. The remaining three tests (aging, endurance, and high speed performance) are still in progress.

\section{Experimental Design}

Four infrequently failed tire brands and four frequently failed tire brands were selected (Ratrout et al., 2002). This categorization was based on observing the brand of failed tires (blow out or tread separation) along four major roads in Saudi Arabia during three months in the summer of 2001. The number of failed tires for each brand together with its market share along the four roads was used as rates to rank the tire brands. The highest and lowest four ranks were selected for this research. It should be emphasized that because of the limited tire sample size in the previous project, the term of frequently and infrequently failed tires should only be taken as a rough measure for segmenting the tire population into two main categories. Consequently, sampling from both categories, simultaneously, should increase the probability of covering a wide spectrum of tire properties and characteristics.

The four infrequently failed tire brands were termed as brands $\mathrm{A}, \mathrm{B}, \mathrm{C}$, and $\mathrm{D}$, while the other four frequently failed tire brands were referred to as brands $\mathrm{E}, \mathrm{F}, \mathrm{G}$ and $\mathrm{H}$. Three tires from each brand were subjected to the testing program. All tires were radial, new, and less than six months old at the time of testing. With the exception of brands $\mathrm{E}$ and F, all tires were of the size 225/70 R15. This size is currently the most frequently used size in the Country. However, brands $\mathrm{E}$ and $\mathrm{F}$ of this size are not imported (Ratrout et al., 2002). Consequently, the next most frequently used size, namely $205 / 65 \mathrm{R} 15$, was selected for these two brands (Ratrout et al., 2002).

\section{Test Procedures}

The visual inspection test recommended by SASO Standard No. 448/1986 (Saudi Arabian Standard Organization, 1986a), requires the tire to be visually inspected by the naked eye, for any cracks or cuts in the tread or sidewalls. Information and markings molded on the tire that are required by SASO Standard No.445/1986 (Saudi Arabian Standard Organization, 1986c), were checked.

The dimension measurement aimed to compare the actual overall width and diameter with the standard values given in SASO Standard No.445/1986 (Saudi Arabian Standard Organization, 1986c). Each tested tire was mounted on a measuring rim and to the pressure specified in the standard, and allowed to stand for 24 hours at room temperature $\left(23 \pm 2^{\circ} \mathrm{C}\right)$. Before conducting the measurements, the pressure was adjusted to the original values and the tire width was callipered at six different points spaced equally around the circumference. This was done using a Vernier caliper having an accuracy of $0.05 \mathrm{~mm}$. The average value of these readings was reported as the section width. The maximum outer circumference was measured with a typical steel tape and then the value was divided by $\pi$ to obtain the overall diameter. These values were then compared with the SASO standard (Saudi Arabian Standard Organization, 1986c).

The bead unseating test evaluates the tire resistance to unseating the tire bead from its rim when subjected to lateral forces such as during severe turning movements. For the tire sizes tested in this paper (section widths $205 \mathrm{~mm}$ and $225 \mathrm{~mm}$ ), this force should not be less than $11,350 \mathrm{~N}$ (Saudi Arabian Standard Organization, 1986b). The tires were washed and dried, mounted on a clean rim and inflated according to the proper pressure specified in the standard at ambient temperature. A material testing machine (INSTRON) was modified to host the tire-wheel assembly horizontally. The testing machine had a force measuring accuracy of $0.5 \%$. The load was applied through the unseating block (shoe) to the tire sidewall at a rate of 50 $\mathrm{mm} / \mathrm{min}$, Figure 1. The load was increased until the bead unseated or until the load of $11,350 \mathrm{~N}$ was reached, whichever happened first (Saudi Arabian Standard Organization, 1986a). For each tire, a sample of six readings was taken at six equally spaced points around the circumference.

The strength test evaluates the strength of the reinforcing material in the tire. According to the previous SASO Standard 447/1986, the bearing energy for the tires tested should not be less than 294 N.m. Each tested tire was mounted on an appropriate rim and inflated to the proper pressure as specified in the standard. The material testing machine (INSTRON), which was used in the bead unseating test, was modified to support a cylindrical steel plunger of $19 \mathrm{~mm}$ diameter with a hemispherical end, Figure 2. The plunger was forced into the tread as near to the centerline as possible at a rate of $50 \mathrm{~mm} / \mathrm{min}$. The distance the plunger moved was reported by an external linear transducer capable of providing an accuracy better than $0.1 \mathrm{~mm}$. Five measurements of force and penetration were taken at points equally spaced around the circumference of the tire. The breaking energy was calculated according to the following formula:

$$
W=\frac{F \times P}{2} \times 10^{-3}
$$

where:

$W=$ Energy at break, N.m

$F=$ Force at break, $\mathrm{N}$

$P=$ Perforation at break, $\mathrm{mm}$ 


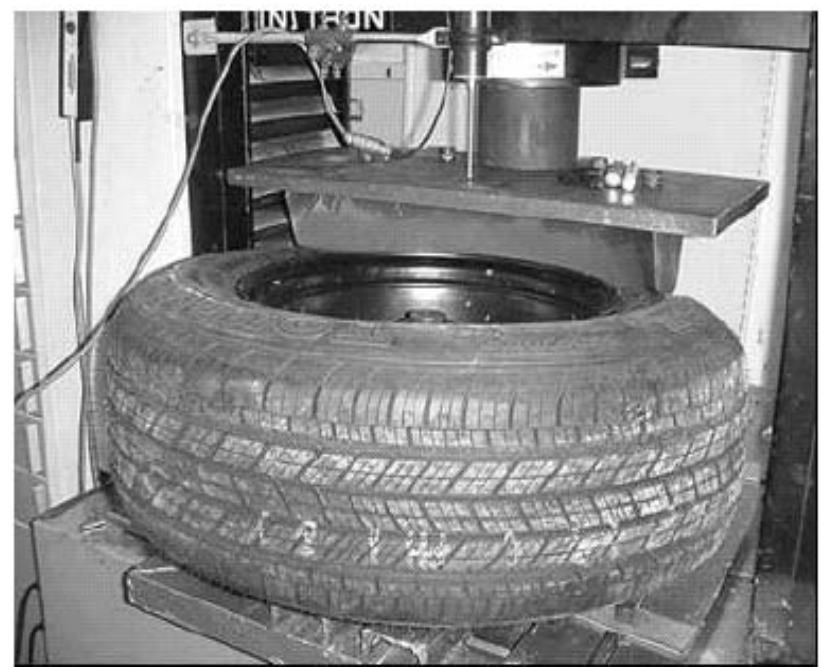

Figure 1. Bead unseating test

The tire was considered to pass the test when the breaking energy was not less than 294 N.m. If the plunger reached the face of the rim without any break occurring (plunger bottoms out), the tire was also considered to pass this test.

The tensile strength and elongation test was conducted using a test specimen of the shape and dimensions shown in Figure 3a and was taken from each tested tire using a press mold, Figure 3b, in the direction of the circumference. The specimen was clamped between the two jaws of a material testing machine (LLOYD LR300K), Figure 4, and stretched at a rate of $500 \pm 25 \mathrm{~mm} / \mathrm{min}$. The testing machine had a force measuring accuracy of $0.5 \%$. The stretch in the specimen was reported by an internal

Table 1. Tire width

\begin{tabular}{|c|c|c|c|c|c|}
\hline \multirow[t]{2}{*}{ Brand } & \multirow[t]{2}{*}{ Size } & \multicolumn{3}{|c|}{$\begin{array}{c}\text { Average Tire Width } \\
\text { (mm) } \\
\text { (\% Coefficient of } \\
\text { Variation) }\end{array}$} & \multirow[t]{2}{*}{$\begin{array}{c}\text { Standard }^{\circ} \\
(\mathrm{mm})\end{array}$} \\
\hline & & Tire 1 & Tire 2 & $\begin{array}{c}\text { Tire } \\
\mathbf{3}\end{array}$ & \\
\hline A & \multirow{4}{*}{ 225/70 R15 } & $\begin{array}{l}232 \\
(0.2)\end{array}$ & $\begin{array}{c}232 \\
(0.2)\end{array}$ & $\begin{array}{c}232 \\
(0.2)\end{array}$ & 220 \\
\hline B & & $\begin{array}{l}229 \\
(0.4)\end{array}$ & $\begin{array}{l}229 \\
(0.4)\end{array}$ & $\begin{array}{c}229 \\
(0.3)\end{array}$ & 220 \\
\hline $\mathrm{C}$ & & $\begin{array}{c}220 \\
(0.4)\end{array}$ & $\begin{array}{c}220 \\
(0.4)\end{array}$ & $\begin{array}{c}221 \\
(0.3)\end{array}$ & 220 \\
\hline $\mathrm{D}$ & & $\begin{array}{l}229 \\
(0.2)\end{array}$ & $\begin{array}{l}229 \\
(0.2)\end{array}$ & $\begin{array}{l}229 \\
(0.2)\end{array}$ & 220 \\
\hline $\mathrm{E}$ & \multirow{2}{*}{ 205/65 R15 } & $\begin{array}{c}214 \\
(0.3)\end{array}$ & $\begin{array}{c}214 \\
(0.3)\end{array}$ & $\begin{array}{c}214 \\
(0.3)\end{array}$ & $* *$ \\
\hline $\mathrm{F}$ & & $\begin{array}{c}211 \\
(0.3)\end{array}$ & $\begin{array}{c}210 \\
(0.5)\end{array}$ & $\begin{array}{l}210 \\
(0.3) \\
\end{array}$ & $* *$ \\
\hline $\mathrm{G}$ & \multirow{2}{*}{$225 / 70$ R15 } & $\begin{array}{c}224 \\
(0.2)\end{array}$ & $\begin{array}{c}231 \\
(0.2)\end{array}$ & $\begin{array}{l}231 \\
(0.2)\end{array}$ & 220 \\
\hline $\mathrm{H}$ & & $\begin{array}{l}235 \\
(0.2)\end{array}$ & $\begin{array}{l}235 \\
(0.2)\end{array}$ & $\begin{array}{c}235 \\
(0.2)\end{array}$ & 220 \\
\hline
\end{tabular}

* SASO Standard No. 445/1986. No tolerance limit given in standard,

**No standard exists

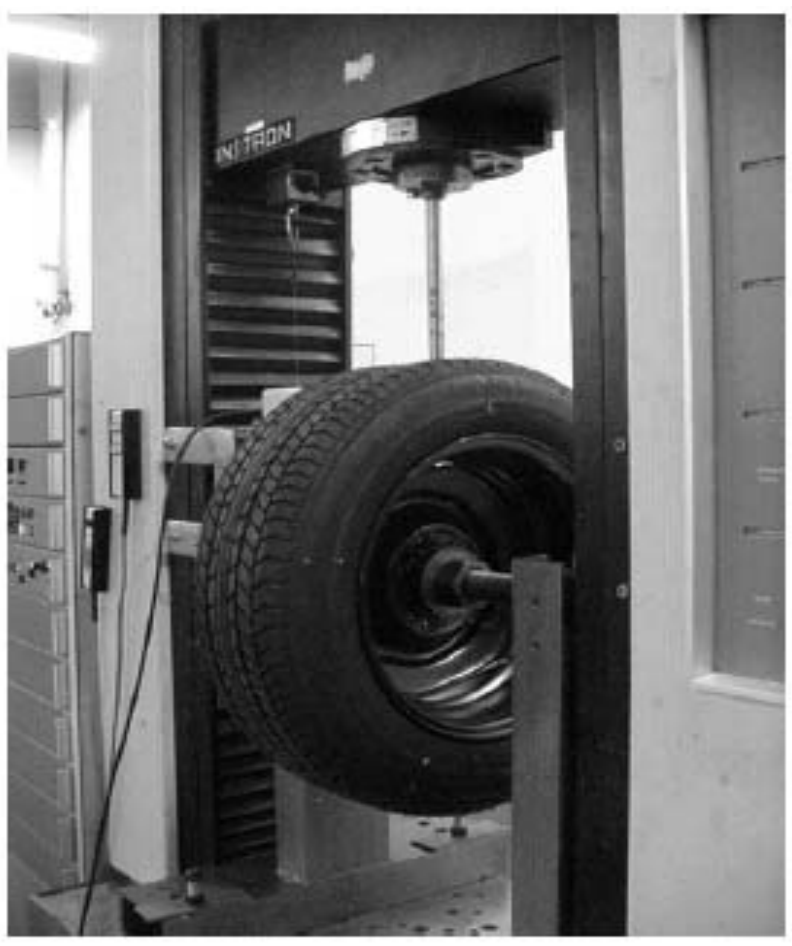

Figure 2. Strength test

extensometer resolution having an accuracy better than $0.005 \mathrm{~mm}$. The tensile strength and elongation were calculated according to the following formula:

$$
T=\frac{L}{A}
$$

and

Elongation $=\frac{I_{2}-I_{1}}{I_{1}} \times 100$

where:

$T=\quad$ Tensile strength, $\mathrm{kg} / \mathrm{mm}^{2}$

$L=\quad$ Maximum load, $\mathrm{kg}$

Table 2. Tire diameter

\begin{tabular}{llcccc} 
Brand & Size & \multicolumn{3}{c}{ Average } & Standard \\
& & \multicolumn{3}{c}{ Diameter $(\mathbf{m m})$} & $(\mathbf{m m})$ \\
& & Tire & Tire & Tire & \\
& & $\mathbf{1}$ & $\mathbf{2}$ & $\mathbf{3}$ & \\
A & & 697 & 697 & 697 & 696 \\
B & $225 / 70$ & 689 & 689 & 689 & 696 \\
C & R15 & 693 & 693 & 698 & 696 \\
D & & 682 & 682 & 689 & 696 \\
E & $205 / 65$ & 632 & 632 & 634 & $* *$ \\
F & R15 & 631 & 631 & 634 & $* *$ \\
G & $225 / 70$ & 679 & 687 & 679 & 696 \\
H & R15 & 679 & 679 & 695 & 696
\end{tabular}

* SASO Standard No. 445/1986. No tolerance limit given in standard, **No standard exists 


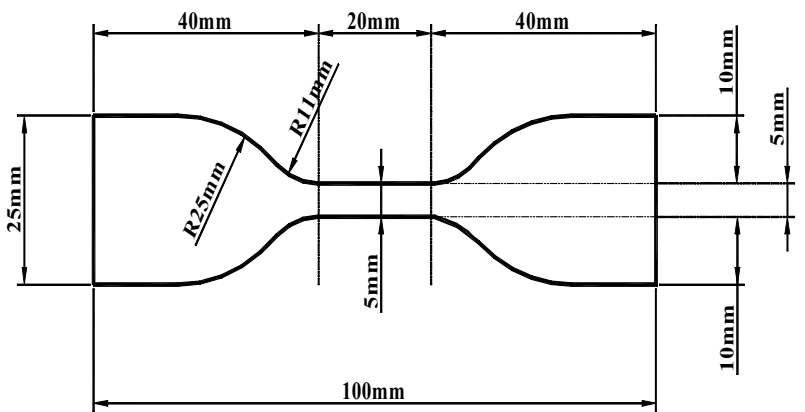

Figure 3a. Dimension of the tensile strength and elongation specimens

$A=\quad$ Cross section area of test specimen, $\mathrm{mm}^{2}$

$I_{1}=\quad$ Standard length

$I_{2}=$ Length at breaking

To pass the SASO standard, the tensile strength of the rubber should not be less than $1.2 \mathrm{~kg} / \mathrm{mm}^{2}$ and the elongation should not be less than 300\% (Saudi Arabian Standard Organization, 1986b). It is interesting to note that the unit used in this test was kilogram rather than Newton. This is inconsistent with the SI system and other SASO tests.

\section{Results}

Visual inspection of the tires revealed that all of them were free from cracks or cuts. All information required by the SASO standards, namely designation of dimensions and construction, designation of tire rim diameter, designation of load and speed, country of origin, date of manufacture and batch number, were present (Saudi Arabian Standard Organization, 1986c). The width measurements

Table 3. Tire unseating

\begin{tabular}{llll}
\hline Brand & \multicolumn{3}{c}{$\begin{array}{c}\text { Average Tire Unseating Values ( N) } \\
\text { (\% Coefficient of }\end{array}$} \\
\cline { 2 - 4 } & Tire 1 & \multicolumn{1}{c}{ Tire 2 } & Tire 3 \\
\hline A & 11,900 & 11,870 & 11,530 \\
& $(0.41)$ & $(0.93)$ & $(0.41)$ \\
B & 11,540 & 11,410 & 11,660 \\
& $(0.74)$ & $(1.52)$ & $(1.63)$ \\
C & 11,570 & 11,760 & 11,880 \\
& $(1.52)$ & $(1.02)$ & $(1.27)$ \\
D & 11,480 & 11,460 & 11,760 \\
& $(1.34)$ & $(1.38)$ & $(1.66)$ \\
E & 11,750 & 11,890 & 11,590 \\
& $(1.61)$ & $(1.41)$ & $(1.40)$ \\
F & 11,680 & 11,530 & 11,930 \\
& $(1.65)$ & $(1.72)$ & $(1.39)$ \\
G & 11,670 & 11,900 & 11,810 \\
& $(1.62)$ & $(0.85)$ & $(1.69)$ \\
H & 11,930 & 11,480 & 11,460 \\
& $(2.07)$ & $(1.53)$ & $(1.57)$ \\
\hline
\end{tabular}

Brand I-IV: Frequently failed brands

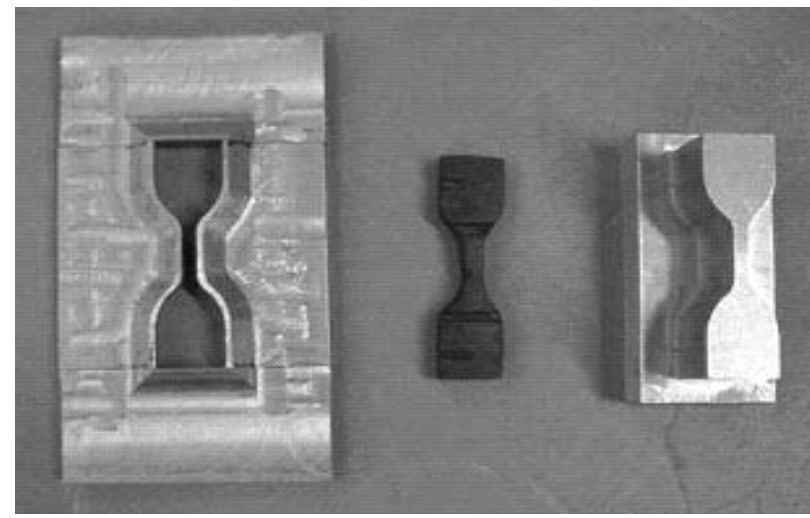

Figure 3b. Shape and mold of the tensile strength and elongation specimens

of the tested tires, Table 1, showed that the coefficient of variation within each tire width measurement never exceeded $0.5 \%$. This indicates that the width of each tire was uniform around its circumference. The diameter measurements in Table 2 show that almost all tire brands had some degree of discrepancy with the SASO standard. The standard does not specify the values for tires of width greater than $195 \mathrm{~mm}$ under the 65 series. Consequently,

Table 4. Tire tensile strength and elongation

\begin{tabular}{|c|c|c|c|c|c|c|}
\hline \multirow[b]{2}{*}{$\begin{array}{l}\text { Tire } \\
\text { Brand }\end{array}$} & \multirow{2}{*}{\multicolumn{2}{|c|}{$\begin{array}{c}\text { Tensile strength } \\
\mathrm{kg} / \mathrm{mm}^{2}(\% \\
\text { Coefficient of } \\
\text { variation) }\end{array}$}} & \multicolumn{4}{|c|}{ Elongation (\%) } \\
\hline & & & \multicolumn{2}{|c|}{$\begin{array}{l}\text { Tread samples** } \\
\text { (\% Coefficient of } \\
\text { variation) }\end{array}$} & \multicolumn{2}{|c|}{$\begin{array}{c}\text { Sidewall } \\
\text { samples } \\
\text { (\% Coefficient } \\
\text { of variation) }\end{array}$} \\
\hline \multirow{3}{*}{ A } & 3.21 & & 331.9 & & 702.0 & \\
\hline & 3.25 & $(1.1)$ & 291.3 & $(65.5)$ & 911.4 & (14.4) \\
\hline & 3.28 & & 56.7 & & 911.4 & \\
\hline \multirow{3}{*}{ B } & 2.80 & & 584.2 & & 498.4 & \\
\hline & 2.82 & $(0.7)$ & 593.8 & $(2.8)$ & 464.3 & (3.6) \\
\hline & 2.84 & & 562.3 & & 475.0 & \\
\hline \multirow{3}{*}{ C } & 2.34 & & 392.2 & & 416.1 & \\
\hline & 2.36 & $(0.6)$ & 272.3 & (19.6) & 416.0 & $(6.2)$ \\
\hline & 2.37 & & 390.8 & & 462.5 & \\
\hline \multirow{3}{*}{ D } & 1.37 & & 113.8 & & 400.4 & \\
\hline & 1.33 & (2.3) & 113.5 & $(39.7)$ & 402.7 & (11.7) \\
\hline & 1.31 & & 50.1 & & 325.2 & \\
\hline \multirow{3}{*}{$\mathrm{E}$} & 0.81 & & 161.3 & & 532.7 & \\
\hline & 0.81 & $(3.5)$ & 6.4 & $(87.6)$ & 506.8 & (2.9) \\
\hline & 0.86 & & 241.0 & & 506.3 & \\
\hline \multirow{3}{*}{$\mathrm{F}$} & 1.19 & & 296.4 & & 405.9 & \\
\hline & 0.90 & $(22.6)$ & 240.0 & (13.6) & 316.4 & (12.4) \\
\hline & 0.77 & & 313.9 & & 375.7 & \\
\hline \multirow{3}{*}{ G } & 1.02 & & 341.7 & & 513.8 & \\
\hline & 0.98 & (4.6) & 295.1 & $(8.7)$ & 521.2 & $(0.8)$ \\
\hline & 0.93 & & 295.0 & & 521.2 & \\
\hline \multirow{3}{*}{$\mathrm{H}$} & 0.51 & & 41.0 & & 511.1 & \\
\hline & 0.53 & $(2.2)$ & 88.4 & $(36.5)$ & 582.8 & $(7.2)$ \\
\hline & 0.53 & & 66.0 & & 578.2 & \\
\hline
\end{tabular}

** The large variation in the elongation is due to the existance of groove on samples 


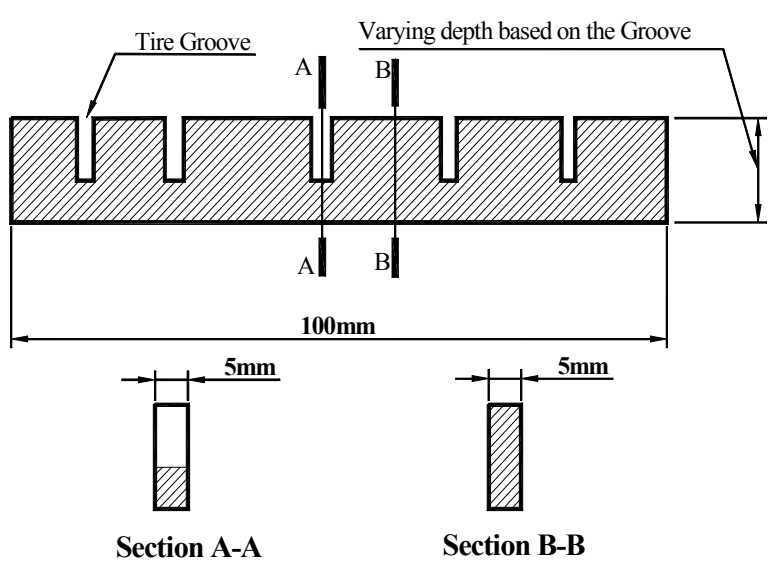

Figure 4a. Longitudinal cross-section of the tensile strength and elongation test

there were no standard values with which brands $\mathrm{E}$ and $\mathrm{F}$ could be compared. However, the average discrepancy for the remaining tires was $7.5 \mathrm{~mm}$ and $9.0 \mathrm{~mm}$ for the diameter and width measurements, respectively. Surprisingly, the SASO dimension standards do not mention any tolerance values for tire dimensions, hence almost all the tested tires did not comply with these standards. Clearly, this is impractical from an engineering point of view. The standard should have some tolerance to account for the accuracy of measuring instruments and other random errors.

The bead unseating test was easily passed by all tire brands, Table 3. It is also interesting to notice that the results in Table 3 show little variation within, and between, different brands. The coefficient of variation within brands was less than $2.1 \%$. The average value for all brands (i.e. 24 tests) was $11,685 \mathrm{~N}$ with a coefficient of variation equal to $1.5 \%$. The U.S. National Highway Safety Administration reported that the bead unseating test and strength test seem to be ineffective in differentiating between radial tires and that these tests are more useful for bias ply tires (National Highway Traffic, 2002 ).

Table 5. T-test analysis for tensile strength test

\begin{tabular}{lcc}
\hline & $\begin{array}{c}\text { Infrequently } \\
\text { failed tires }\end{array}$ & $\begin{array}{c}\text { Frequently } \\
\text { failed tires }\end{array}$ \\
\hline Mean $\left(\mathrm{kg} / \mathrm{mm}^{2}\right)$ & 2.44 & 0.82 \\
Variance & 0.551 & 0.04 \\
Observations & 12 & 12 \\
Pooled variance & 0.298 & \\
Hypothesized mean & 0 & \\
difference & 22 & \\
Df & 7.27 & \\
T Stat & $1.4 \times 10^{-7}$ & Reject $\mathrm{H}_{\mathrm{o}}$ \\
$\mathrm{P}(\mathrm{T} \leq \mathrm{t})$ one-tail & 1.72 & \\
$\mathrm{~T}$ Critical one -tail & $2.8 \times 10^{-7}$ & Reject $\mathrm{H}_{\mathrm{o}}$ \\
$\mathrm{P}(\mathrm{T} \leq \mathrm{t})$ two -tail & 2.07 & \\
$\mathrm{~T} \mathrm{Critical} \mathrm{two} \mathrm{-tail}$ & & \\
\hline
\end{tabular}

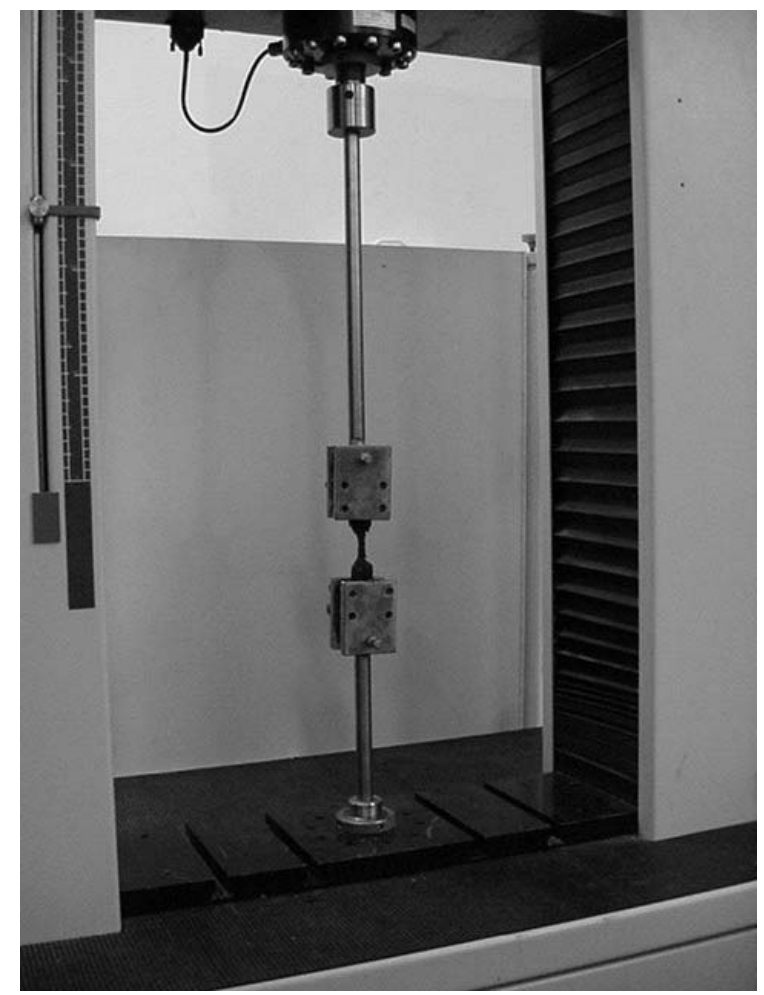

Figure 4b. Tensile strength and elongation test

In the strength test, the results for all tires were so good that the plunger reached the bottom (rim surface) without breaking the reinforcement material in the tread. This seemed to be consistent with what is being reported in the U.S. The National Highway Traffic Safety Administration has recently reported that this strength test, which was originally designed for evaluating the strength of bias ply tires, was not so effective in testing radial tires (National Highway Traffic, 2002). They also reported that "because of the belt package, radial tires far exceed the strength requirements of the test and many times the plunger bottoms out on the rim instead of breaking reinforcement material in the radial tire" (National Highway Traffic, 2002). The U.S. Rubber Manufacturer Association members also reported conducting about 19,000 strength tests on radial tires, none of which failed (National Highway Traffic, 2002).

The results of the tensile strength test for our study, Table 4, show that the variation within each brand is small. The coefficient of variation was less than $5 \%$ for all brands except brand $\mathrm{F}$. The latter had a value of $22.6 \%$, Table 4. Brands A-D (infrequently failed) passed the strength requirement of $1.2 \mathrm{~kg} / \mathrm{mm}^{2}$. On the other hand, none of the frequently failed tires (brands E-H) passed this requirement. The average strength was $2.44 \mathrm{~kg} / \mathrm{mm}^{2}$ for the infrequently failed tires and $0.82 \mathrm{~kg} / \mathrm{mm}^{2}$ for the frequently failed tires. These two averages are statistically unequal at a significance level of $0.05 \%$, Table 5 .

The elongation test results for the tread samples was inconsistent and the variation within brands was high. The coefficient of variation ranged from $88 \%$ for brand $\mathrm{E}$ and 
$2.8 \%$ for brand B, Table 4 . A possible reason for this variation was the fact that the cross-sections of the samples were not uniform due to the existence of the groove in the tire tread, Figures $4 \mathrm{a}$ and $4 \mathrm{~b}$. This resulted in a non-uniform strain along the sample length. With the exception of brand $\mathrm{B}$, none of the brands passed the required $300 \%$ elongation value in all of the three tire samples tested. Only $33 \%$ of the tested tires passed this test. More specifically, $50 \%$ of the tires in the infrequently failed brands category, and $17 \%$ from the frequently failed brands category, passed the elongation requirements.

\section{Conclusions}

The dimensions of almost all the tested tires were at variance with the SASO standards. The average difference was $7.5 \mathrm{~mm}$ and $9.0 \mathrm{~mm}$ for the diameter and section width, respectively. However, it is not known whether these differences are acceptable from a safety and operational point of view. It might be beneficial for the standard to include some tolerance value for the dimensions, to overcome this shortcoming.

All the tested tires easily passed the bead unseating and the strength tests. Both tests seem not to be stringent enough for radial tires.

The infrequently failed tires passed the tensile strength test with an overall average value of $2.44 \mathrm{~kg} / \mathrm{mm}^{2}$. Whereas, none of the frequently failed tires was able to reach the $1.2 \mathrm{~kg} / \mathrm{mm}^{2}$ strength required to pass this test. The overall average tensile strength of these frequently failed tires was $0.82 \mathrm{~kg} / \mathrm{mm}^{2}$. This was statistically different from the average value of the infrequently failed tires at a 95\% confidence level. Consequently, this tensile strength test seemed to be useful in the screening of imported radial tires. The elongation test results were inconsistent for the tread samples because of the existence of grooves in the tire tread. Due to the erratic elongation results, another set of specimens were taken from the sidewall of the tire to avoid the effects of the groove. The results of these specimens appeared to be more consistent and to have less variation within brands. The coefficient of variation was less than $15 \%$ for all the tested brands, Table 4. The use of sidewall specimens to measure the elongation gave better results. In this case, some adjustment to the specifications may be needed to determine the allowable minimum value since all results passed the minimum required elongation of $300 \%$.

\section{Recommendations}

Our research study indicated that the SASO standards need to be critically reviewed and updated. Dimension standards should be completed for all tire sizes and reasonable tolerance in the dimension standard should be considered. All units in the SASO standards should be consistent and should follow the SI system. The bead unseating test and the strength test are not stringent enough for radial tires. The merits of these two tests for radial tires should be studied and appraised. In the tensile strength and elongation test, it is recommended to use the sidewall specimens in measuring elongation and to adjust the passing minimum value accordingly.

\section{Acknowledgements}

The authors would like to acknowledge the financial support of King Abdulaziz City for Science and Technology and King Fahd University of Petroleum \& Minerals.

\section{References}

Ministry of Commerce \& Saudi Arabian Standards Organization, 2002, "International Conformity Certification Program for Exporting Countries: Comprehensive Procedures and Guidelines," August 2001 (www.iccp.com).

National Highway Traffic Safety Administration, Department of Transportation, 2001, "Federal Motor Vehicle Safety Standard No. 109; New Pneumatic Tires," Code of Federal Regulations, Title 49, Volume 5, Revised as of October 1, 2001 from the U.S. Government Printing Office via GPO Access (http/frwebgate.access.gpo.gov).

National Highway Traffic Safety Administration, 2002 "Notice of Proposed Rulemaking: Federal Safety Standard; Tires," Docket No. NHTSA-00-8011, Federal Register: March 5, 2002 (www.nhtsa.dot.gov/cars/rules/rulings/tread/MileSton es/ 66FRPg10049 .html).

Ratrout, N.T. et al., 2002, "Tire Failure - Reasons and Consequences," 1st Interim Report, King Abdulaziz City for Science and Technology, 1423H.

Saudi Arabian Standards Organization, 1986a, "Passenger Car Tires, Part 3: Methods of Test," SASO Standard No. 448/1986, Riyadh, Saudi Arabia.

Saudi Arabian Standards Organization, 1986b, "Passenger Car Tires, Part 2: General Requirements," SASO Standard No. 447/1986, Riyadh, Saudi Arabia.

Saudi Arabian Standards Organization, 1986c, "Passenger Car Tires, Part 1: Nomenclature, Designation, Marking, Dimensions, Load Capacity and Inflation Pressure," SASO Standard No. 445/1986, Riyadh, Saudi Arabia. 